Biol Neonate 1988;54:I-VI

\title{
Contents, Vol. 54, 1988
}

\section{No. 1 Review}

Brain Development in the Fetus, Neonate and Infant

Herschkowitz, N 1

Original Paper

Vitamin D Deficiency, Pancreatic and Small Intestinal Enzyme Development in Rats

Jirapinyo, P.; Srimaruta, N.; Lebenthal, E.; Lee, P.-C

Impairment of Superoxide Release by Alveolar Macrophage in Rats Exposed to Oxygen and Vitamin E

Nakamura, H.; Takada, S.; Sano, K.; Komura, M.; Matsuo, T.; Ohara, H 28

Influence of Hydrocortisone on the Development of Pancreas in Suckling Rats. Ultrastructural Morphometric and Biochemical Studies

Puccio, F.; Chariot, J.; Lehy, T 34

Effect of Bupivacaine Hydrochloride on Bilirubin Production in Neonatal Rats

Gale, R.; Vreman, H.J.; Ferguson, J.E., II; Stevenson, D.K 44

Vasoactive Compound Effects on Autoregulating versus Nonautoregulating Intestinal and Renal Circulations in Young Swine

Buckley, N.M.; Diamant, S.; Frasier, I.D.; Owuau, K

Announcement 60

No. 2 Original Paper

Respiratory Failure Caused by Intratracheal Saline: Additive Effect of Xanthine Oxidase Saugstad, O.D.; Hallman, M.; Becher, G.; Oddoy, A.; Lium, B.; Lachmann, B 61 Percutaneous Respiration in the New-Born Infant. Effect of Ambient Oxygen Concentra tion on Pulmonary Oxygen Uptake

Cartridge, P.H.T.; Rutter, N 68

In vivo and in vitro Effects of Theophylline on the Peripheral Blood Mononuclear Cells from Preterm Infants

Bessler, H.; Sirota, L.; Gilgal, R.; Dulitzky, F.; Djaldetti, M 73

Homeothermal Adjustment in the Immediate Postdelivered Infant Monitored by Contin uous and Simultaneous Measurement of Core and Peripheral Body Temperatures

Kubota, S.; Koyanagi, T.; Hori, E.; Hara, K.; Shimokawa, H.; Nakano, H 79

Pituitary Changes of Desacetyl- $\alpha$-Melanocyte-Stimulating Hormone throughout Develop ment

Facchinetti, F.; Storchi, A.R.; Furani, S.; Radi, D.; Genazzani, A.R 86

IV

Contents

Urocytogram, an Index of Maturity in Premature Infants

Robine, N.; Relier, J.P.; Le Bars, S 93

Lung Glycogen Metabolism in Suckling Rats: A Comparative Study

Maritz, G.S 100 
Development of the Rat Hepatic Microsomal Glucose-6-Phosphatase System and Its Glucocorticoid Inducibility

Burchell, A.; Leakey, J.E.A 107

Vascular Placental Insufficiency in the Rabbit. Changes in Creatine Kinase and Adenylate Kinase Activities in Fetal Tissues

Harel, S.; Sömjen, D.; Earon, Y.; Tomer, A.; Kaye, A.M.; Kariv, N.; Binderman, I. .116

No. 3 Original Paper

Evidence for Functional Immaturity of the Ornithine-Urea Cycle in Very-Low-Birth-

Weight Infants

Boehm, G.; Müller, D.M.; Beyreiss, K.; Räihä, N.C.R

Alanine Turnover Rate and Its Hepatic Metabolism Are Increased in Midpregnant Rat

Pastor-Anglada, M.; Champigny, O.; Ferré, P.; Remesar, X.; Girard, J 126

Glycogen Metabolism in Late Gestation in Fetuses of Maternal Diabetic Rats

Margolis, R.N.; Seminara, D 133

Age-Dependent Effects of ß2-Adrenergic-Stimulating Drugs on Fetal Rabbit Lung Liquid and Adrenal Catecholamines

Lundell, K.-H.; Bergman, B.; Svensson, K.; Hedner, T 144

Impact of Protein-Calorie Malnutrition on the Developing Intestine. A Model in Young

Rabbits

Decker Butzner, J.; Grant Gall, D 151

Regulation of Growth Hormone Release in Fetal Calves

Coxam, V.; Davicco, M.-J.; Dardillat, C; Robelin, J.; Lefaivre, J.; Opmeer, F.; Barlet, J.-P 160

Beta Blockers Inhibit Fetal Thromboxane A2 Production in vitro

Viinikka, L.; Ylikorkala, $0 \quad 169$

Copper Metabolism in the Macular Mutant Mouse: An Animal Model of Menkes's Kinky-

Hair Disease

Shiraishi, N.; Aono, K.; Taguchi, T 173

No. 4 Editorial

Perinatal Vitamin D Metabolism

Salle, B.L.; Glorieux, F.H.; Delvin, E.E 181

Original Paper

Spectral Analysis of Impedance Respirogram in Newborn Infants

Äärimaa, T.; Välimäki, I.A.T 188

Concentration of Hypoxanthine in both Cerebrospinal Fluid and Brain Tissue Increases

under Intensive Hypoxia Only

Lun, A.; Gross, J.; Siggel, H.; Pohle, R

Maternal Treatments with Corticosteroids and/or T3 Change Lung Volumes and Rupture

Pressures in Preterm Rabbits

ElKady, T.; Jobe, A 203

Contents

$\mathrm{V}$

Effects of Antenatal Hydrocortisone on Tidal Volumes in Spontaneously Breathing Preterm Newborn Rabbits. Possible Mediation by Adrenal Catecholamines

Hedner, T.; Bergman, U.; Freyschuss, U.; Grossmann, G.; Robertson, B 211

Renal Effects of í/-Tubocurarine and Pancuronium in the Newborn Rabbit 
Gouyon, J.-B.; Torrado, A.; Guignard, J.-P. . . - - 218

Impact of Nutrition on Postnatal Development of Serine-Threoine Dehydratase and Branched-Chain Keto Acid Dehydrogenase in the Rat

Grogan, C.K.; Janas, L.M.; Hendrix, M.K.; Layman, D.K.; Picciano, M.F 224

Perinatal Brain Serotonin Metabolism in Rats Malnourished in utero

Manjarréz, G.; Chagoya, G.; Hernandez, J 232

No. 5 Original Paper

Alterations of Serum High-Density Lipoproteins and Hepatic Lipase Activity in Congenital

Hypothyroidism Tenenbaum, D.; Gambert, P.; Fischbach, M.; d'Athis, P.; Nivelon, J.-L;

Lallemant, C. 241

Single-Dose Captopril Scintigraphy in the Neonate with Renovascular Hypertension: Prediction of Renal Failure, a Side Effect of Captopril Therapy

Sfakianakis, G.N.; Sfakianaki, E.; Paredes, A.; Abitbol, C; Zilleruelo, G.; Goldberg,

R.N.; Strauss, J 246

Effect of Indomethacin on Cerebral Blood Flow Velocity of Premature Newborns

Laudignon, N.; Chemtob, S.; Bard, H.; Aranda, J.V 254

Maternal-Fetal Transfer of Fluoride in Pregnant Women

Caldera, R.; Chavinie, J.; Fermanian, J.; Tortrat, D.; Laurent, A.M 263

Sialic Acid Content and Sialyltransferase Activity in Lymphocytes from Neonates

Komlos, L.; Levinsky, H.; Goldman, J.; Peleg, D.; Halbrecht, I.; Allalouf, D 270

Phenylalanine Uptake in Neonatal and Infant Rat Brain

McChesney, R.; Habermann, J.; Greengard, 0275

Effect of Premature Delivery on Rat Lung Retinol (Vitamin A) and Retinyl Ester Stores

Zachman, R.D.; Valceschini, G 285

Interaction of Insulin with Small Intestinal Epithelial Cells from Developing Rats

Fernandez-Moreno, M.D.; Fernández-González, M.A.; Diaz-Juárez, J.L.; López-Luna,

M.P.; Prieto, J.C 289

Neonatal and Adult Copper-64 Metabolism in the Pig and the Possible Relationship

between the Ontogeny of Copper Metabolism and Wilson's Disease

Bingle, CD.; Srai, S.K.S.; Whiteley, G.S.W.; Epstein, 0294

No. 6 Original Paper

Patterns of Serum Glucose and Galactose Concentrations in Term Newborn Infants after

Milk Feeding

Siegel, CD.; Sparks, J.W.; Battaglia, F.C 301

Head Position in Low-Risk Premature Infants. Impact of Nursing Routines

Vies, J.S.H.; Oostenbrugge, R. van; Kingma, H.; Caberg, H.; Casaer, P 307

Transcutaneous Bilirubinometry. Effect of Irradiation on the Skin Bilirubin Index

Yamauchi, Y.; Yamanouchi, $1 \quad 314$

Fetal Alcohol Syndrome in Rats: Conditions for Improvement of Ethanol Effects on Fetal

Cerebral Development with Supplementary Agents

Tanaka, H.; Iwasaki, S.; Nakazawa, K.; Inomata, K 320

VI

Contents

Corticosteroid Increases Gastrointestinal Luminal Proteolysis in Suckling Rats

Britton, J.R.; Koldovský, $0 \quad 330$

Excessive Doses of Cerulein Stimulate Pancreatic Growth in Suckling Rats but Damage the 
Pancreas of Weaned Rats

Papp, M.; Dobronyi, I.; Varga, G 339

Prenatal Protein-Energy Malnutrition Alters Various Biochemical Components of the Membranous Bones in Fetal Rats

Miwa, T.; Shoji, H.; Solomonow, M.; Nakamoto, T 347

Glucose Homeostasis in the Newborn. Effects of Oral Feeding on Response to Fasting and Intravenous Glucose Infusion in Neonatal Piglets

Flecknell, P.A.; Wootton, R.; Royston, P.; John, M 356

Author Index 363

Subject Index 365 